\title{
Diel vertical distribution of planktonic microcrustaceans (Crustacea: Cladocera, Copepoda) in a natural shallow lake from Transylvania, Romania
}

\author{
Karina P. BATTES, ${ }^{*}$ Laura MOMEU \\ Department of Taxonomy and Ecology, Babeş-Bolyai University, 5-7 Clinicilor Str., 400006, Cluj-Napoca, Romania \\ *Corresponding author: karina.battes@gmail.com
}

\begin{abstract}
The diel vertical migration (DVM) of planktonic cladocerans and copepods was investigated in Lake Ştiucii, a natural shallow lake from north-western Romania. The aim of this study was to test the existence of migration patterns for cladocerans, adult copepods and copepod development stages (copepodites and nauplii) in four sampling seasons: October 2004; January, April and July 2005. The main abiotic and biotic factors influencing the microcrustacean day and night distributions were also analyzed: water temperature, dissolved oxygen, transparency; the distribution of planktonic algae at midday and at midnight in July and the number of larvae of the dipteran predator Chaoborus present in the plankton samples. For most microcrustaceans, nighttime biomass exceeded the daylight values in the water column, indicating a strategy of predator avoidance by staying near to the bottom of the lake during the day. Normal DVM patterns (up at night and down during the day) were observed for cladocerans and adult copepods, while for copepodites and nauplii no clear patterns were depicted. Negative correlations between daytime vertical profiles of planktonic algae and microcrustacean biomass revealed that both cladocerans and copepods migrated away from phytoplankton-rich waters during the day, to escape visual predators like fish. The return in the water column during the night was influenced by invertebrate predation pressure, exerted by Chaoborus larvae.
\end{abstract}

Key words: Lake Ştiucii, DVM, microcrustaceans, abiotic conditions, biotic factors, seasonal change.

Received: October 2013. Accepted: December 2013.

\section{INTRODUCTION}

Microcrustaceans are an important group of freshwater zooplankton: they occupy an intermediate trophic level, controlling the abundances of their prey but also functioning as food source for invertebrate and vertebrate predators. The diel vertical migration (DVM) in the water column represents one of the most conspicuous and welldocumented behaviour of zooplankton in pelagic habitats. The vertical distribution patterns are very diverse. They can vary from one species to another, within the developmental stage of a species, but also for the same species from one season to another (Lampert and Sommer, 2007). Usually, zooplankton swims to deep waters during the day and moves back up during night time. Reverse migration patterns are also common, while some zooplankton may not migrate at all.

Habitat preferences influence the vertical distribution of zooplankton. These preferences depend on temperature (Gliwicz and Pijanowska, 1988; Haney 1993), dissolved oxygen (Horppila et al., 2000; Chang and Hanazato, 2004), while the changes in light intensity are known to be the primary cue for vertical migrations (Ringelberg et al., 1991; Ringelberg and Van Gool, 2003). The vertical distribution of zooplankton may be caused by a complex of factors including not only abiotic ones, like temperature, but also biotic drivers, like food availability and quality
(Jakobsen and Johnsen, 1987; Leibold, 1990; Lampert et al., 2003; Pearre, 2003), predation (Beklioglu et al., 2008) or competition (Larsson, 1997). Predator pressure can trigger vertical migrations in zooplankton, which influence the distribution of algae in the water column, forming cascading migrations (Bollens et al., 2011). Many authors agree that predator avoidance plays a key role in controlling vertical migrations of zooplankton (Kozhov, 1963; Zaret and Suffern, 1976; Neill, 1990; Lampert, 1993). Thus, normal migrating zooplankton move to deeper, darker waters during the day, to avoid visual predators, mostly fish, that usually do not tolerate low oxygen concentrations (Wright and Shapiro, 1990). However, invertebrate predators, like Chaoborus larvae, may also survive in conditions of critical oxygen concentrations (Rine and Kesler, 2001), thus reverse vertical migration patterns are usually correlated with the invertebrate predator pressure (Neill, 1990; Lampert, 1993). Freshwater zooplankton has been well studied in Romanian continental waters, especially in the Danube Delta. However, analyses on DVM are considered in just a few studies from a deep dam reservoir in eastern Romania, Lake Izvorul Muntelui - Bicaz; and the data are either old (Rujinschi and Rujinschi, 1970), or inconclusive (Erhan, 2008).

The main objectives of this study were to investigate the occurrence of DVM for planktonic microcrustacean populations in a natural shallow lake from north-western 
Romania and to examine the relative importance of biotic and abiotic factors in determining the migration patterns.

\section{Study site}

Lake Ştiucii, a Nature Reserve since 1966, represents one of the few Transylvanian aquatic ecosystems not heavily affected by human activities. It is a freshwater meso-eutrophic lake, with a surface of 57.35 ha and a volume of $1780000 \mathrm{~m}^{3}$, surrounded by a think belt of paludal vegetation, mainly Phragmites communis. Its mean depth is about $3 \mathrm{~m}$, while the maximum depth is $6.8 \mathrm{~m}$. It is located at $274.5 \mathrm{~m}$ altitude above sea level, on the Bonţ Rivulet, part of the Someşul Mic catchment area (Şerban and Sorocovschi, 2003) (Fig. 1).

Lake Ştiucii represents a typical temperate dimictic lake, with spring and autumn mixing periods. The first one usually begins in late February/early March, once the ice cover melts away and the winter inverse stratification stops, while the latter usually occurs at the end of September. The water source of the lake is represented mainly by superficial runoff, which accounts for about $70-80 \%$ from the total water supply (Şerban and Sorocovschi, 2003). Human impacts are not severe in Lake Ştiucii; they are mostly represented by runoffs from the agricultural and pasture fields near the lake, tourism and fish stocking. Lake Ştiucii is now included in Natura 2000 network.

\section{METHODS}

\section{Sample collection and analyses}

The data for this study were collected in October 2004; January, April and July 2005, from the area of max-

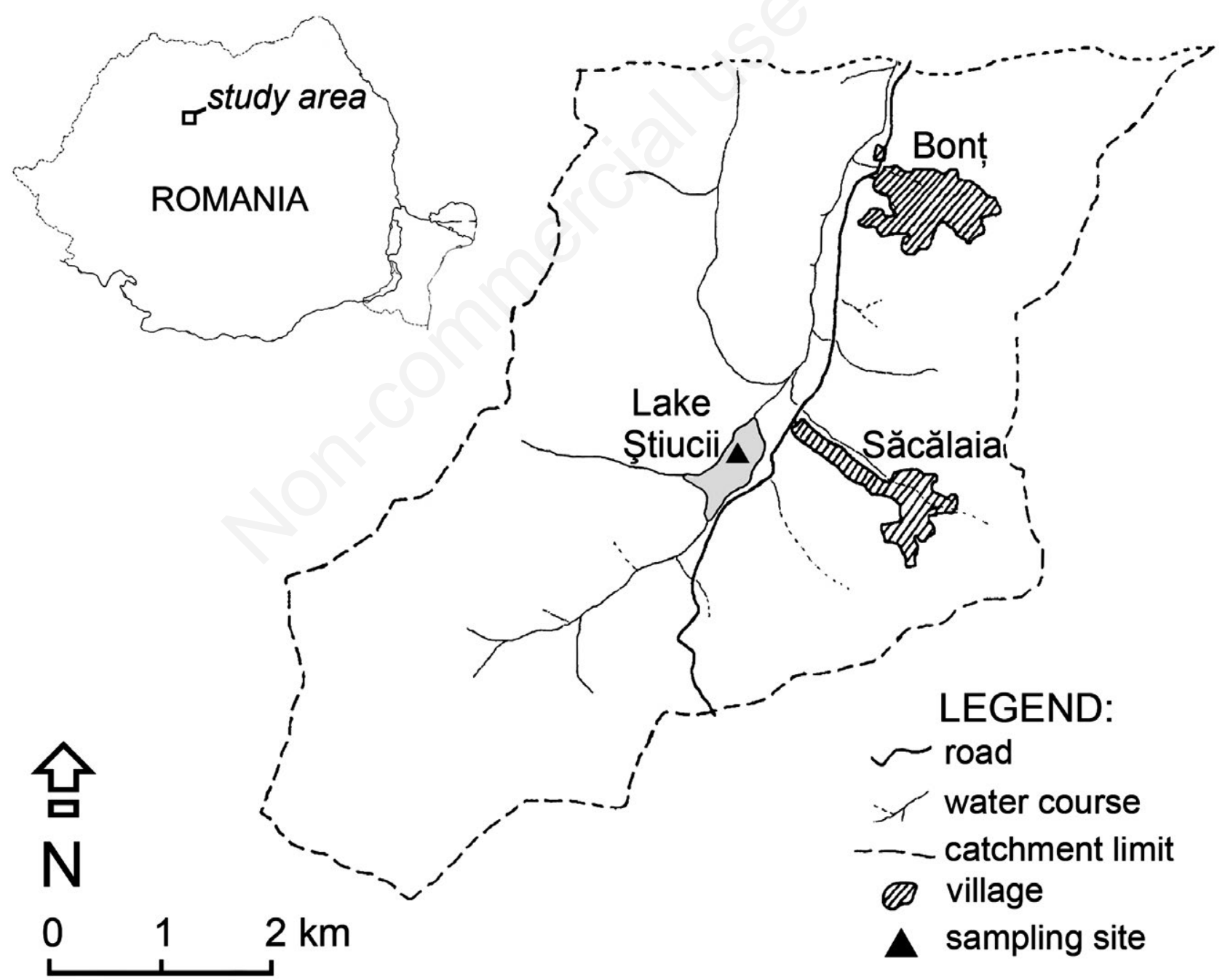

Fig. 1. Location of Lake Ştiucii in the upper catchment area of the Bonţ Rivulet, in north-western Romania (modified from Şerban and Sorocovschi, 2003). 
imum depth located in the lake center (N 46.9676; E 23.9015). Samplings were carried out six times during a $24 \mathrm{~h}$ period. The samples were collected at $1 \mathrm{~m}$ depth intervals, from the surface $(0 \mathrm{~m})$ to near the bottom $(6 \mathrm{~m})$, using a $10 \mathrm{~L}$ Schindler-Patalas trap and a $55-\mu \mathrm{m}$ mesh zooplankton net. Three replicates were collected from each depth. The samples were fixed with sugar formalin at a final concentration of 4\% (Haney and Hall, 1973). At each sampling date, water temperature $\left({ }^{\circ} \mathrm{C}\right)$ and dissolved oxygen $\left(\mathrm{mg} \mathrm{L}^{-1}\right)$ were measured in a vertical profile, every one meter, using an YSI-52 DO-meter. Water transparency (m) was also recorded at 12:00 h with a Secchi disk. Planktonic algae were sampled in July 2005 at 12:00 h and 00:00 h, from the same depth intervals as zooplankton. Ten liters of lake water were filtered using a $30-\mu \mathrm{m}$ mesh net. Phytoplankton samples were also fixed with formalin at a final concentration of 4\%. Larvae of the dipteran Chaoborus were found in zooplankton samples in all seasons. Even though no benthic samples were collected, the number of phantom midge larvae was used in data interpretation as a general indicator of invertebrate predation pressure.

Identifications to the species level were carried out under a Nikon YS100 microscope for zooplankton and Nikon Eclipse E400 for phytoplankton. Three cladoceran species and two copepod species, together with copepodites and nauplii were considered for the present study. Counts were performed under a Nikon SZM645 dissecting microscope and microcrustacean density (ind. $\mathrm{L}^{-1}$ ) was calculated according to Clesceri et al. (1998). Biomass was estimated using length-weight regression equations. Data from Bottrell et al. (1976) were considered for Bosmina longirostris (nonovigerous parthenogenetic females and males), Cyclops vicinus and Thermocyclops crassus. Equations from Culver et al. (1985) were used for nauplii and Bosmina longirostris (ovigerous parthenogenetic females and gamogenetic females); while the biomass for copepodites, Ceriodaphnia pulchella and Daphnia cucullata was calculated using Michaloudi (2005). A total number of 11499 individuals were measured, following the recommendations given by Culver et al. (1985). Biomass values were given in $\mu \mathrm{g} \mathrm{L}^{-1}$ dry weight. For phytoplankton samples, counts were performed under the microscope considering the dominant genera and the relative percentage abundance was calculated for each sampling hour. A total of 3961 individuals were counted for the day samples $(12: 00 \mathrm{~h})$ and 4839 individuals for the night ones (00:00 h).

\section{Statistical methods}

Testing the existence of DVM required a clear distinction between day and night. In October 2004 and January 2005 , the daylight samples collected at 08:00 h, 12:00 h and 16:00 $\mathrm{h}$ represented the day sample, while the ones col- lected at 20:00 h, 00:00 $\mathrm{h}$ and 04:00 $\mathrm{h}$ constituted the night sample. However, in April and July 2005, the sunset took place at 20:25 h and 21:00 h, respectively (http://www. timeanddate.com/), thus daytime samples were considered those taken at 08:00 h, 12:00 h, 16:00 h and 20:00 h.

Day and night distributions of microcrustacean biomass were calculated from the average values of the six sampling times separated into day and night samples, from the surface to near the bottom. These distributions were compared using the nonparametric two-sample Kolmogorov-Smirnov test that enables the similarity of the distributions to be tested at the same time as their shape and position. Significant differences between day and night according to the Kolmogorov-Smirnov test were considered to be an indicator of the existence of DVM. Mann-Whitney test was also used to compare the day and night values of water temperature and dissolved oxygen. The average depth of microcrustacean vertical distribution was quantified using the weighted mean depth (WMD), adapted from Frost and Bollens (1992):

$$
W M D=\frac{\sum b_{i} d_{i}}{\sum b_{i}}
$$

where $b_{i}$ is the biomass of species $i$ (dry weight, $\mu \mathrm{g} \mathrm{L}^{-1}$ ) at depth $d_{i}$, taken to be the midpoint of each depth stratum. This parameter showed the depth at which the large majority of microcrustaceans resided during daytime and at night. The migration amplitude was calculated as the difference between the WMD values, positive results indicating normal migration pattern (descendant movements during the day and ascendant during the night), while negative results showing reverse migration patterns.

Correlations between microcrustacean distributions, abiotic factors, phytoplankton variables and Chaoborus numbers were tested using both parametric and nonparametric tests (Pearson $r$ and Spearman $r_{s}$, respectively), depending on the normal distribution of data (tested with Shapiro-Wilk W normality test).

\section{RESULTS}

\section{Diel vertical distribution of microcrustaceans}

Eleven microcrustacean species were identified in the sampling dates: seven cladoceran and four copepod taxa, together with copepodites and nauplii (Tab. 1). Only species that recorded at all depths and at all sampling hours an average biomass higher than $10 \mu \mathrm{g} \mathrm{L}^{-1}$ dry weight were selected for the analysis (underlined values in Tab. 1). Copepodites and nauplii also met this criterion.

Microcrustacean biomass calculated for all six sampling hours was averaged to obtain the daytime biomass and the nighttime biomass for each sampling date. The percentage of day and night biomass in the water column, from the surface to near the bottom (the relative abun- 
Tab. 1. Average biomass ( $\mu \mathrm{g} \mathrm{L}^{-1}$ dry weight) of the microcrustaceans present at the sampling dates in Lake Ştiucii (asterisks indicate selected species, underlined values exceed the threshold).

\begin{tabular}{|c|c|c|c|c|}
\hline \multirow[t]{2}{*}{ Microcrustaceans } & \multicolumn{4}{|c|}{ Sampling months } \\
\hline & October 2004 & January 2005 & April 2005 & July 2005 \\
\hline \multicolumn{5}{|l|}{ Cladocerans } \\
\hline Alona rectangula Sars 1862 & 0.008 & - & 0.006 & 0.011 \\
\hline Bosmina longirostris (O.F. Müller 1776)* & $\underline{94.749}$ & $\underline{53.823}$ & $\underline{124.829}$ & $\underline{61.116}$ \\
\hline Ceriodaphnia pulchella Sars $1862^{*}$ & 1.799 & - & 0.049 & $\underline{34.674}$ \\
\hline Chydorus sphaericus (O.F. Müller 1776) & - & - & 0.011 & - \\
\hline Daphnia cucullata Sars $1862^{*}$ & 28.781 & $\underline{18.163}$ & 7.253 & 2.092 \\
\hline Pleuroxus aduncus (Jurine 1820) & - & - & - & 0.002 \\
\hline Simocephalus vetulus (O.F. Müller 1776) & 0.058 & - & - & 0.002 \\
\hline \multicolumn{5}{|l|}{ Copepods } \\
\hline Cyclops vicinus Ulianine $1875^{*}$ & 7.921 & 341.269 & $\underline{82.535}$ & 0.355 \\
\hline Macrocyclops albidus (Jurine 1820) & 0.017 & - & - & - \\
\hline Mesocyclops leuckarti (Claus 1857) & 0.021 & - & 0.327 & 5.214 \\
\hline Thermocyclops crassus (Fischer 1853) ${ }^{*}$ & 7.182 & - & 1.125 & 22.081 \\
\hline copepodites $^{*}$ & $\underline{60.738}$ & $\underline{869.972}$ & 40.353 & 24.963 \\
\hline nauplii* & $\underline{13.195}$ & 50.622 & $\underline{47.906}$ & $\underline{27.482}$ \\
\hline
\end{tabular}

dance) was estimated from the total biomass recorded at every sampling date. All cladocerans and adult copepods recorded higher biomass percentages during the night (Figs. 2, 3 and 4). Differences in their biomass between day and night ranged from 21 to $86 \mu \mathrm{g} \mathrm{L}^{-1}$ on the average. For copepodites and nauplii however, higher night biomass values were recorded only in April (Fig. 5). In the other three sampling months, daytime biomass percentages slightly exceeded the night ones (with biomass differences ranging from 0.8 to $13 \mu \mathrm{g} \mathrm{L}^{-1}$ on the average), except for January, when the difference between day and night biomass reached $436 \mu \mathrm{g} \mathrm{L}^{-1}$ on the average for copepodites. Average biomass variation during a $24 \mathrm{~h}$ period recorded constant minimum values at 16:00 h for cladocerans and adult copepods, in all sampling months (Fig. 6), with only two exceptions: B. longirostris and C. pulchella in July. These minima were followed by maximum biomass values at 20:00 $\mathrm{h}$ in October, January and April; and at 00:00 h or 04:00 h in July. Copepodites also recorded the 16:00 h minimum in all sampling months except July, but for nauplii no clear patterns were observed.

All cladoceran species exhibited significant differences in their vertical distributions between day and night, according to the Kolmogorov-Smirnov test, thus showing DVM in all months considered for the present study (Tab. 2). Test results were also significant for the two species of copepods, except for $C$. vicinus in January. For copepodites and nauplii, significant differences between their day and night distributions were showed in two months out of four, as depicted in Tab. 2. WMD values showed the depth where the large majority of microcrustaceans resided during daytime and at night (Tab. 3). Dif-

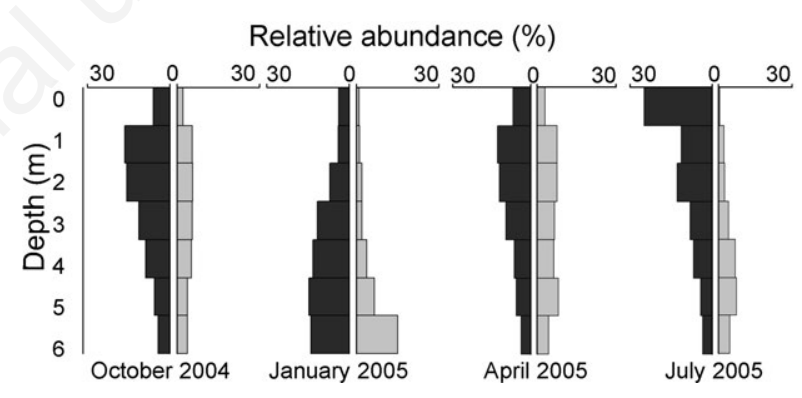

Fig. 2. Vertical distribution of biomass relative abundance (\%) for Bosmina longirostris in Lake Ştiucii during the day (grey areas) and at night (black areas).

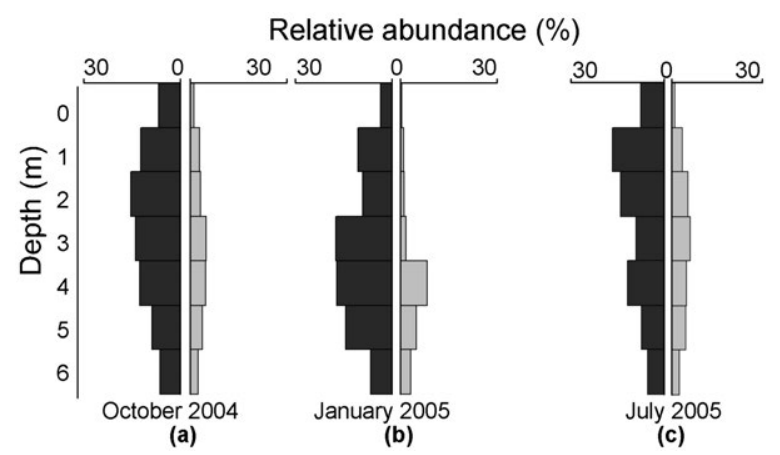

Fig. 3. Vertical distribution of biomass relative abundance (\%) of Daphnia cucullata (a, b) and Ceriodaphnia pulchella (c) during the day (grey areas) and at night (black areas). 
ferences between day and night WMDs were used to calculate the migration amplitude and the pattern of the DVM, when Kolmogorov-Smirnov test results were significant. Cladocerans and adult copepods recorded normal DVM because night WMDs were shallower compared to day values. Their migration amplitudes ranged from nearly $0.5 \mathrm{~m}$ to over $2 \mathrm{~m}$, with the highest values recorded by $B$. longirostris in July. Copepodites and nauplii however recorded lower migration amplitudes, not exceeding $0.5 \mathrm{~m}$, with reverse DVM in January (Tab. 3).

\section{Water temperature, dissolved oxygen and Secchi transparency}

Water temperature recorded normal values for temperate dimictic lakes. However, a true mixing of water strata occurred only in October. The beginning of the thermal stratification was clear in April, with differences up to $6^{\circ} \mathrm{C}$ between the water surface and the maximum depth; and with a drop of an average $3.2^{\circ} \mathrm{C}$ between 3 and $4 \mathrm{~m}$. Summer stratification was recorded in July; the thermocline was located between 3 and $5 \mathrm{~m}$ deep, where a drop of more than $10^{\circ} \mathrm{C}$ occurred. Inverse winter stratification was observed in January, when the temperatures ranged from around $0^{\circ} \mathrm{C}$ at the surface, to $4^{\circ} \mathrm{C}$ at the bottom. Despite this seasonal variance of water temperatures in the water column, the differences between day and night were minimal. Slight differences were recorded for dissolved oxygen values, with higher daytime concentrations in some cases, but no significant results were observed (Mann-Whitney $\mathrm{U}>14 ; \mathrm{P}>0.2$ in all four seasons). The depth of hypoxic layer $\left(<1.5 \mathrm{mg} \mathrm{O}_{2} \mathrm{~L}^{-1}\right)$ differed in the water column in the sampling months: it was located at 6 $\mathrm{m}$ in October and January, at $5 \mathrm{~m}$ in July and at $4 \mathrm{~m}$ in April. A clinograde oxygen profile was recorded in October, January and April; while the metalimnetic oxygen

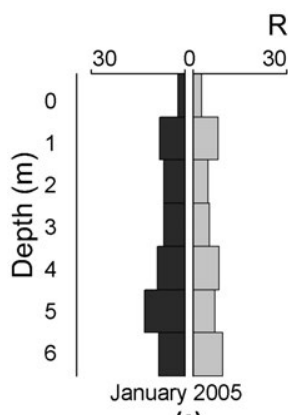

(a)
Relative abundance (\%)

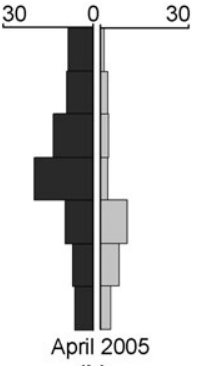

(b)

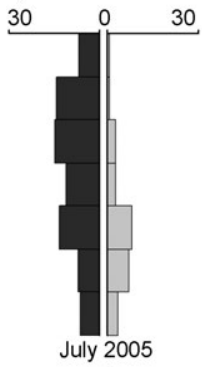

(c)
Fig. 4. Vertical distribution of biomass relative abundance (\%) of adult copepods: Cyclops vicinus (a; b) and Thermocyclops crassus (c) in Lake Ştiucii during the day (grey areas) and at night (black areas). maximum at $4 \mathrm{~m}$ deep led to a positive heterograde curve in July. The low dissolved oxygen values at $3 \mathrm{~m}$ deep in July influenced the vertical distribution of microcrustaceans: at 12:00 $\mathrm{h}$ for example, all microcrustaceans recorded a very low biomass at that depth (Fig. 7). The Secchi-disc transparency ranged from $1.64 \mathrm{~m}$ in April, to $2 \mathrm{~m}$ in October and July, and $2.25 \mathrm{~m}$ in January.

(a) copepodites Relative abundance (\%)

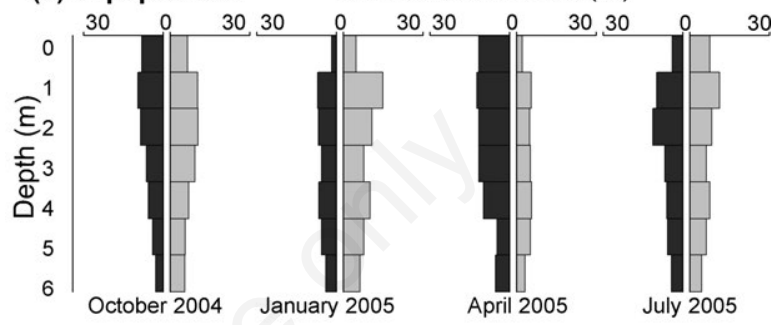

(b) nauplii

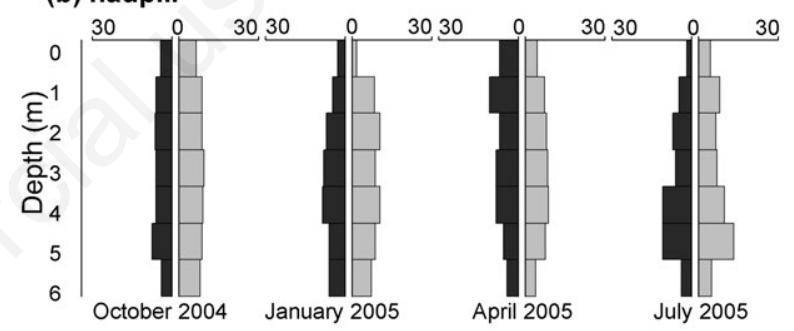

Fig. 5. Vertical distribution of biomass relative abundance (\%) of copepodites (a) and nauplii (b) in Lake Ştiucii during the day (grey areas) and at night (black areas).

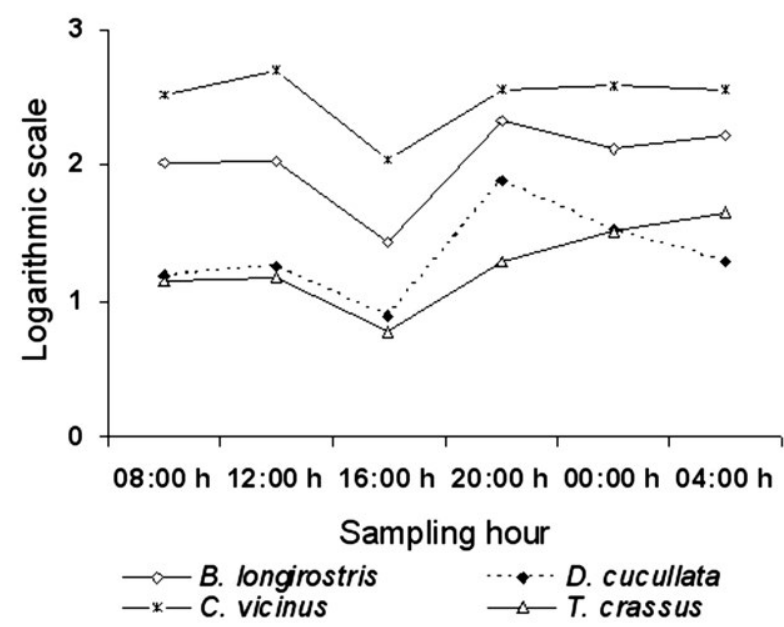

Fig. 6. Variation of average biomass during a $24 \mathrm{~h}$ interval for: Bosmina longirostris in April 2005; Daphnia cucullata in October 2004; Cyclops vicinus in January 2005 and Thermocyclops crassus in July 2005 (logarithmic transformation based on $\log _{10}$ ). 
Tab. 2. Values of the Kolmogorov-Smirnov test on microcrustacean depth distributions at the six sampling times (08:00 h, 12:00 h, 16:00 h, 20:00 h, 00:00 h and 04:00 h) in Lake Ştiucii (P values in brackets).

\begin{tabular}{|c|c|c|c|c|}
\hline \multirow[t]{2}{*}{ Microcrustaceans } & \multicolumn{4}{|c|}{ Sampling months } \\
\hline & October 2004 & January 2005 & April 2005 & July 2005 \\
\hline \multicolumn{5}{|l|}{ Cladocerans } \\
\hline Bosmina longirostris & $\begin{array}{c}0.71429 \\
(0.00809)\end{array}$ & $\begin{array}{c}0.71429 \\
(0.00789)\end{array}$ & $\begin{array}{c}0.85714 \\
(0.00589)\end{array}$ & $\begin{array}{c}0.85714 \\
(0.00460)\end{array}$ \\
\hline Ceriodaphnia pulchella & $\begin{array}{l}- \\
-\end{array}$ & $\begin{array}{l}- \\
-\end{array}$ & $\begin{array}{l}- \\
-\end{array}$ & $\begin{array}{c}0.85714 \\
(0.00579)\end{array}$ \\
\hline Daphnia cucullata & $\begin{array}{c}1.00000 \\
(0.00009)\end{array}$ & $\begin{array}{c}0.71429 \\
(0.00809)\end{array}$ & - & $\begin{array}{l}- \\
-\end{array}$ \\
\hline \multicolumn{5}{|l|}{ Copepods } \\
\hline Cyclops vicinus & - & $\begin{array}{c}0.28571 \\
(0.96360)\end{array}$ & $\begin{array}{c}0.71429 \\
(0.00869)\end{array}$ & $\begin{array}{l}- \\
-\end{array}$ \\
\hline Thermocyclops crassus & - & - & - & $\begin{array}{c}0.71429 \\
(0.00789)\end{array}$ \\
\hline copepodites & $\begin{array}{c}0.28571 \\
(0.96230)\end{array}$ & $\begin{array}{c}0.71429 \\
(0.00889)\end{array}$ & $\begin{array}{c}0.71429 \\
(0.00719)\end{array}$ & $\begin{array}{c}0.57143 \\
(0.20980)\end{array}$ \\
\hline nauplii & $\begin{array}{c}0.85714 \\
(0.00420)\end{array}$ & $\begin{array}{c}0.71429 \\
(0.00749)\end{array}$ & $\begin{array}{c}0.28571 \\
(0.96280)\end{array}$ & $\begin{array}{c}0.28571 \\
(0.96090)\end{array}$ \\
\hline
\end{tabular}

Tab. 3. Weighted mean depth of microcrustaceans calculated for day and night samples in Lake Ştiucii.

\begin{tabular}{|c|c|c|c|c|c|}
\hline \multirow[t]{2}{*}{ Microcrustaceans } & \multirow[t]{2}{*}{ WMD (m) } & \multicolumn{3}{|c|}{ Sampling months } & \multirow[b]{2}{*}{ July 2005} \\
\hline & & October 2004 & January 2005 & April 2005 & \\
\hline \multicolumn{6}{|l|}{ Cladocerans } \\
\hline Bosmina longirostris & $\begin{array}{l}\text { Day } \\
\text { Night } \\
\text { Difference }\end{array}$ & $\begin{array}{l}3.519 \\
3.003 \\
0.516\end{array}$ & $\begin{array}{l}5.233 \\
4.340 \\
0.893\end{array}$ & $\begin{array}{l}3.579 \\
2.983 \\
0.596\end{array}$ & $\begin{array}{l}4.423 \\
2.329 \\
2.094\end{array}$ \\
\hline Ceriodaphnia pulchella & $\begin{array}{l}\text { Day } \\
\text { Night } \\
\text { Difference }\end{array}$ & $\begin{array}{l}- \\
- \\
-\end{array}$ & $\begin{array}{l}- \\
- \\
-\end{array}$ & $\begin{array}{l}- \\
- \\
-\end{array}$ & $\begin{array}{l}3.730 \\
3.119 \\
0.611\end{array}$ \\
\hline Daphnia cucullata & $\begin{array}{l}\text { Day } \\
\text { Night } \\
\text { Difference }\end{array}$ & $\begin{array}{l}3.765 \\
3.358 \\
0.407\end{array}$ & $\begin{array}{l}4.617 \\
3.815 \\
0.802\end{array}$ & $\begin{array}{l}- \\
- \\
-\end{array}$ & $\begin{array}{l}- \\
- \\
-\end{array}$ \\
\hline Copepods & & & & & \\
\hline Cyclops vicinus & $\begin{array}{l}\text { Day } \\
\text { Night } \\
\text { Difference }\end{array}$ & $\begin{array}{l}- \\
- \\
-\end{array}$ & NS & $\begin{array}{l}4.251 \\
3.299 \\
0.952\end{array}$ & $\begin{array}{l}- \\
- \\
-\end{array}$ \\
\hline Thermocyclops crassus & $\begin{array}{l}\text { Day } \\
\text { Night } \\
\text { Difference }\end{array}$ & $\begin{array}{l}- \\
- \\
-\end{array}$ & $\begin{array}{l}- \\
- \\
-\end{array}$ & $\begin{array}{l}- \\
- \\
-\end{array}$ & $\begin{array}{l}4.528 \\
3.257 \\
1.271\end{array}$ \\
\hline copepodites & $\begin{array}{l}\text { Day } \\
\text { Night } \\
\text { Difference }\end{array}$ & NS & $\begin{array}{c}3.331 \\
3.600 \\
-0.269\end{array}$ & $\begin{array}{l}3.382 \\
2.935 \\
0.447\end{array}$ & NS \\
\hline nauplii & $\begin{array}{l}\text { Day } \\
\text { Night } \\
\text { Difference }\end{array}$ & $\begin{array}{l}3.578 \\
3.533 \\
0.045\end{array}$ & $\begin{array}{c}3.799 \\
3.804 \\
-0.005\end{array}$ & NS & NS \\
\hline
\end{tabular}

WMD, weighted mean depth; NS, Kolmogorov-Smirnov test not significant. 
No significant correlations were observed between water transparency and microcrustacean WMDs or their migration amplitudes. No significant correlations were observed between microcrustacean average biomass vertical distribution and water temperature or dissolved oxygen in October. In January however, cladoceran and adult copepod vertical biomass profile was positively correlated with water temperature and negatively correlated with dissolved oxygen (for example, Spearman $r_{s}=0.964$; $\mathrm{P}=0.0004$ for the correlation between $B$. longirostris daytime biomass and the water temperature profile). In July, the correlation between daytime biomass of $B$. longirostris and the water temperature was negative (Spearman $\mathrm{r}_{\mathrm{s}}=-0.893 ; \mathrm{P}=0.012$ ), while the nighttime biomass profile was positively correlated with water temperature (Spearman $\mathrm{r}_{\mathrm{s}}=0.964 ; \mathrm{P}=0.0004$ ), thus indicating diel changes in its biomass vertical distribution.

\section{Phytoplankton and Chaoborus larvae}

Seven algal phyla were identified in Lake Ştiucii in July 2005 , at midday $(12: 00 \mathrm{~h})$ and at midnight $(00: 00 \mathrm{~h})$ : Chlorophyta (41 species); Dinophyta (4 species); Cyanoprokaryota (3 species); Bacillariophyta (2 species); Chrysophyta, Cryptophyta and Euglenophyta (with one species each). The counts were performed considering the dominant genera in day and night samples, as follows: the green algae Cosmarium, Staurastrum and Eutetramorus; the dinoflagellates Ceratium and Peridinium and the chrysophyte Dinobryon. Dinobryon was identified only at midday; Eutetramorus only at midnight, while the other genera were found in both day and night samples. During the day, the highest number of individuals was recorded at $3 \mathrm{~m}$ in the water column. At night, planktonic algae had a main peak at the surface, followed by secondary peak at $3 \mathrm{~m}$. Negative correlations were observed between microcrustaceans and planktonic algae at 12:00 h. For example, a significant negative correlation was recorded between $B$. longirostris and Dinobryon (Spearman $\mathrm{r}_{\mathrm{s}}=-0.929 ; \mathrm{P}=0.007$ ) or between T. crassus and Dinobryon (Spearman $\mathrm{r}_{\mathrm{s}}=-0.857$; $\mathrm{P}=0.012)$. For the night sample $(00: 00 \mathrm{~h})$, only positive correlations were observed, like the correlation between $B$. longirostris and Ceratium (Spearman $\mathrm{r}_{\mathrm{s}}=-0.929 ; \mathrm{P}=0.007$ ) or between $T$. crassus and Staurastrum (Spearman $\left.\mathrm{r}_{\mathrm{s}}=-0.929 ; \mathrm{P}=0.007\right)$. These tendencies are depicted in Fig. 8 .

Data on Chaoborus were acquired solely from zooplankton samples; no benthic samples were collected, no pupae were found and no distinction was made between the larval instars. However, high numbers of Chaoborus larvae were considered an indicator of high predation pressure. The total number of Chaoborus larvae found in plankton samples ranged from 16 in October to 73 in January, 25 in April and 51 in July. The highest numbers were observed in waters deeper than $4 \mathrm{~m}$ in all sampled months, with two exceptions: January at 08:00 $\mathrm{h}$ and July at 00:00 $\mathrm{h}$, when the larvae were caught in shallow waters (no more than $2 \mathrm{~m}$ deep). The number of Chaoborus larvae was significantly negatively correlated with water temperature and dissolved oxygen. Significant correlations were also recorded between the vertical distributions of Chaoborus larvae and the microcrustacean ones at the sampling hours $(08: 00 \mathrm{~h} ; 12: 00 \mathrm{~h} ; 16: 00 \mathrm{~h} ; 20: 00 \mathrm{~h} ; 00: 00$

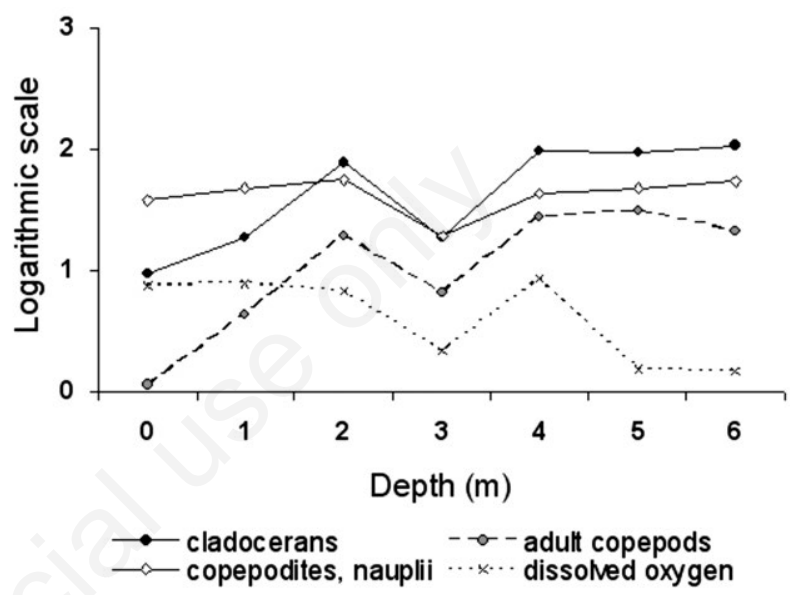

Fig. 7. Dissolved oxygen $\left(\mathrm{mg} \mathrm{L}^{-1}\right)$ and microcrustacean biomass ( $\mu \mathrm{g} \mathrm{L}^{-1}$ dry weight) at 12:00 h in July 2005 in Lake Ştiucii; cladocerans: Bosmina longirostris and Ceriodaphnia pulchella (sum of biomass values); adult copepods: Thermocyclops crassus; logarithmic transformation as follows: $\log _{10}$ (original values +1 ).

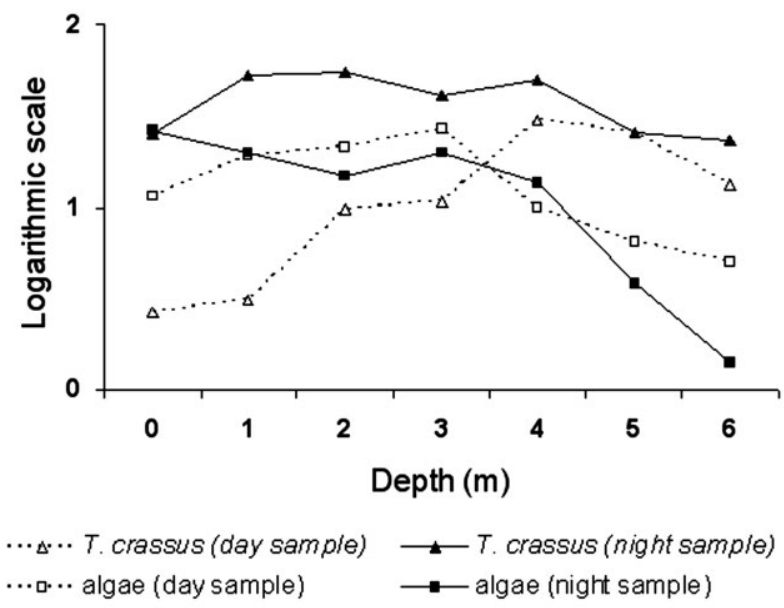

Fig. 8. Relative abundance of planktonic algae (\%) and the biomass of Thermocyclops crassus ( $\mu \mathrm{g} \mathrm{L}^{-1}$ dry weight) in day and night samples from July 2005 in Lake Ştiucii (logarithmic transformation based on $\log _{10}$ ). 
$\mathrm{h}$ and 04:00 h). Thus, significant positive correlations were observed between $B$. longirostris and $D$. cucullata biomass distributions from $0 \mathrm{~m}$ to near the bottom and the vertical Chaoborus distributions in October, and January (Pearson $\mathrm{r}=0.884 ; \mathrm{P}=0.020$ and $\mathrm{r}=0.962 ; \mathrm{P}=0.020$, respectively, for $B$. longirostris; and Pearson $\mathrm{r}=0.962 ; \mathrm{P}=0.009$ and $\mathrm{r}=0.905 ; \mathrm{P}=0.013$, respectively, for $D$. cucullata). Similar positive correlation was characteristic to vertical distributions of C. vicinus and Chaoborus larvae in April (Pearson $\mathrm{r}=0.867 ; \mathrm{P}=0.025$ ). In July however, negative significant correlations were recorded between the dipteran larvae vertical distributions and those of $B$. longirostris (Spearman $\mathrm{r}_{\mathrm{s}}=-0.886 ; \mathrm{P}=0.017$ ) and $C$. pulchella (Spearman $\mathrm{r}_{\mathrm{s}}=-0.886 ; \mathrm{P}=0.017$ ).

\section{DISCUSSION}

\section{Diel vertical migration of microcrustaceans}

Testing the existence of DVM for planktonic microcrustaceans from shallow lakes can be challenging, due to several reasons. Firstly, cladoceran and copepod species usually record a high variation of biomass from one season to another, while some are present only as durable eggs in winter. As a consequence, it is difficult to include all the species in DVM analyses. This problem was overcome here by choosing only five microcrustacean species (from a total of eleven), with biomass values exceeding a certain threshold; $B$. longirostris was the only species with a constant high biomass from one season to another. Secondly, migratory behaviour can vary seasonally for the same population living in the same habitat, in response to changes of environmental variables (Stich and Lampert, 1981; Ringelberg et al., 1991; Lampert and Sommer, 2007). That is why DVM is discussed here with respect to three groups: cladocerans, adult copepods and development copepod stages (copepodites and nauplii). The existence of DVM for cladocerans and adult copepods was clearly showed by higher night biomass values, in some cases twice as large as daytime values. Similar findings were reported in the literature; Chang and Hanazato (2004) for example observed higher densities of Leptodora kindtii and Mesocyclops in the water column of a shallow temperate lake during the night than during the day. These biomass differences between day and night suggest that both cladocerans and adult copepods stayed just above the bottom during the day, avoiding sampling, and migrated upward during the night. Low daytime biomass could also imply a diel horizontal migration (DHM) towards the shallower waters near the banks, where submerged macrophytes could offer shelter against predators. However, the sampling site was located in the central area of the lake, at least $150 \mathrm{~m}$ away from the nearest bank. An individual of $B$. longirostris, swimming with an average speed of 1.5-2 $\mathrm{mm} \mathrm{s}^{-1}$ (Zaret and Kerfoot, 1980) would need 21 to $27 \mathrm{~h}$ to reach the edge of the lake, so DHM is highly questionable in this case.

Significant differences between day and night distributions in the water column indicated DVM for cladocerans and adult copepods, except for C. vicinus in January. Moreover, their night WMDs, located in shallower waters compared to day WMDs, certified the normal pattern of migration. Their amplitudes of migration, calculated as differences between day and night WMDs, recorded the highest value for the small-body cladoceran $B$. longirostris in July, contrary to the fact that larger, more conspicuous individuals usually exhibit greater migration amplitudes (Wright et al., 1980; Lampert and Sommer, 2007). The migration amplitudes in October for cladocerans and adult copepods were lower compared to any other season, probably because of the mixing of the water layers, characteristic to autumn in dimictic lakes. In April and July on the other hand, higher amplitudes of migration were recorded, but no species succeeded in surpassing the barrier of the thermocline, except for $B$. longirostris, whose night WMD was located well above the thermocline. The amplitude of DVM for copepods decreased with age, from higher values for adult $T$. crassus to minimum amplitudes for nauplii. This ontogenetic trend of the copepod DVM amplitude was described in the literature for Thermocyclops inversus (Bezerra-Neto and Pinto-Coelho, 2007).

For copepodites and nauplii, no clear trends were discernible. Day and night biomass were comparable, with one exception; significant differences between day and night distributions were confirmed for only two sampling months out of four and the differences between day and night WMDs showed reverse DVM in January, but with very low amplitudes. Thus, the presence of a clear DVM for both nauplii and copepodites in Lake Ştiucii should be regarded with caution. Rujinschi and Rujinschi (1970) had similar findings in Lake Izvorul Muntelui - Bicaz.

\section{Abiotic factors and microcrustacean diel vertical migration}

The distribution of microcrustaceans in the water column was strongly influenced by temperature and dissolved oxygen profiles, depending on the sampling season. For example, during autumn mixing period, no significant relationships were recorded between the biomass distribution and water temperature, but during the winter inverse stratification, microcrustaceans preferred the deeper, warmer waters.

In July, the $3 \mathrm{~m}$ deep metalimnetic minimum of dissolved oxygen profile led to low microcrustacean biomass values at that depth. This positive heterograd oxygen profile is usually caused by decreases in oxygen concentrations from epilimnion and hypolimnion during summer stratification, but also by algal populations that develop 
more rapidly than they sink out of the deeper waters (Wetzel, 2001). This might explain the high oxygen concentration at $4 \mathrm{~m}$ in Lake Ştiucii that month, even if planktonic algae recorded their maximum percentage at $3 \mathrm{~m}$. The lack of a perfect overlap between the two peaks could be caused by the composition of planktonic algal community in the water column. Unlike green algae, both dinophytes and chrysophytes include forms with heterotrophic nutrition, capable of ingesting particles like bacteria or eukaryotic cells. Ceratium and Dinobryon for example, are two dominant algal genera, known to be both autotrophic and holozoic (Dragoş et al., 1997). Hence, the phytoplanktonic photosynthesis might not be directly related to oxygen concentration in this case.

On the other hand, in all sampling seasons, the microcrustacean WMDs were located above the deep hypoxic water layer, except for $C$. vicinus in April, thus showing a high toleration to oxygen depletion. The DVM of zooplankton may be influenced by water clarity, expressed as Secchi disc transparency (Dodson, 1990; Lampert and Sommer, 2007). Indeed, day WMDs of all microcrustaceans were located deeper in the water column at higher transparency values in Lake Ştiucii, suggesting that seasonal changes in water clarity influenced the depth of residence of most microcrustaceans.

\section{Biotic factors and microcrustacean diel vertical migration}

Most copepod species, in their later development stages and as adults are efficient predators, feeding mostly on protozoans and rotifers, but also on small cladocerans or algae (Santer, 1993; Brandl, 2005; Chang and Hanazato, 2005). However, all significant correlations between cladoceran and copepod densities in Lake Ştiucii were positive, so the predation pressure of $C$. vicinus and T. crassus on cladocerans remained unclear.

The $24 \mathrm{~h}$ variation of microcrustacean biomass recorded minimum values for cladocerans, adult copepods and copepodites at 16:00 $\mathrm{h}$ in October, January and April. At that hour there was plenty of light in all three sampling months, and temperature recorded the highest values in the shallow waters (from 0 to $2 \mathrm{~m}$ deep). This microcrustacean retreat from the water column at 16:00 h could serve the purpose of escaping predators that feed visually, like fish (in accordance with the predator-avoidance hypothesis, Kozhov, 1963; Lampert and Sommer, 2007). Since fish are cold blooded, temperature controls their metabolism, feeding and reproduction (Cole, 1983), so higher temperatures would increase their activity and the amount of food required. Thus, the highest fish predatory pressure would take place at the highest daytime temperatures, at 16:00 h. Microcrustaceans represent a valuable food resource for fish species in Lake Ştiucii: in an ichthyofauna survey conducted in July 2004 using gill nets with different mesh sizes, cladocerans and copepods were identified in half of the dissected fish stomachs. For example, D. cucullata and C. pulchella were present in high numbers in the stomachs of six out of the ten fish species caught in Lake Ştiucii, with averages reaching 200 individuals / stomach (Battes et al., 2005). The study results showed a balanced fish community, including carnivorous, but mostly non-carnivorous fish species that can exert a high predatory pressure on microcrustaceans inducing distinctive vertical $24 \mathrm{~h}$ profiles with minimum biomass at 16:00 h. Subsequently, most microcrustaceans recorded a maximum biomass at night: at 20:00 $\mathrm{h}$ in October and January and 00:00 h in April, when they return in the water column, probably pushed by the high numbers of Chaoborus larvae that left the sediment to feed. Chaoborus larvae are known to prey heavily on zooplankton (Neill, 1981). In Lake Ştiucii, Chaoborus larvae were numerous in deep waters and at night. This trend could be mainly due to lower risk of visual predation by fish (Lampert, 1993; Sæther, 1997). They also showed the normal pattern of DVM in the water column, down during the day and up at night, as described in the literature for Chaoborus flavicans from fish-abundant lakes (Gliwicz et al., 2000; Oda and Hanazato, 2008). However, the highest number of larvae in July was recorded during the day. This result corresponds with the findings of Halat and Lehman (1996): Chaoborus larvae living in warm seasons need more food to survive than those living in colder conditions, so they have to spend more time searching for food in the water column. Indeed, the only specimens of Chaoborus larvae found at 00:00 h in July were at 2 and $3 \mathrm{~m}$ deep in the water column in Lake Ştiucii, and they probably pushed $B$. longirostris to cross the thermocline to avoid the invertebrate predators.

All six dominant genera of planktonic algae counted in day and night samples from Lake Ştiucii are recognized as possible food items for both cladocerans and copepods, especially green algae. However, Ceratium hirundinella (a dominant dinophyte in Lake Ştiucii) is not ingested by herbivorous cladocerans (Sommer et al., 2003), but adult cyclopoids and copepodites might consume it, although it is not a preferred food source (Santer, 1996). Peridinium (another dominant dinophyte genus) is also known to be inversely related to cyclopoid numbers (Low et al., 2010). Moreover, a higher body size can be achieved by planktonic algae as defense strategy to avoid grazing: body projections for Staurastrum; large single-celled organisms for Peridinium; colonies for Dinobryon (Lampert and Sommer, 2007). Negative correlations between day samples for algae and microcrustaceans showed that cladocerans and adult copepods left the shallow phytoplankton-rich waters to escape predatory pressure during the day. Positive correlations for night samples indicated the return of microcrustaceans into shallow waters, to feed. 


\section{CONCLUSIONS}

The present study demonstrated the existence of normal DVM in microcrustaceans in a natural shallow lake, using a holistic approach that took into consideration both abiotic and biotic factors within the ecosystem. Most of the microcrustaceans considered here clearly showed different distributions during the day and at night, while changes were also visible from one season to another. The analyses focused on cladocerans and adult copepods, which showed normal DVM: down during the day and up at night, with low migration amplitudes. For copepodites and nauplii, results were inconclusive. The most important cause for DVM in Lake Ştiucii appeared to be predation pressure, coming not only from the fish community but also from the dipteran Chaoborus, whose larvae were present in numerous zooplankton samples.

\section{ACKNOWLEDGMENTS}

The study was supported by the National Council for Scientific Reasearch (CNCSIS - Consiliul Naţional al Cercetării Ştiinţifice din Învăţământul Superior), grant no. 155/2003-2005. Thanks are due to our colleagues: Daniel Țura, Claudia Nagy (Pavelescu), Levente Nagy, Paula Apetrei for their help during the filed and laboratory work; and to professor Claudiu Tudorancea, Mirela Cîmpean, Ioana Meleg and Anca Avram (Timar) for their valuable comments on the manuscript.

\section{REFERENCES}

Battes KP, Battes KW, Stoica I, 2005. The occurence of zooplanktonic microcrustaceans in the diet of natural fish populations from Lake Ştiucii (Natural Reserve, Cluj County). St. Cercet. Şt. Biol. Bacău 10:95-100.

Bezerra-Neto JF, Pinto-Coelho RM, 2007. Diel vertical migration of the copepod Thermocyclops inversus (Kiefer, 1936) in a tropical reservoir: the role of oxygen and the spatial overlap with Chaoborus. Aquat. Ecol. 41:535-545.

Beklioglu M, Gozen AG, Yildirim F, Zorlu P, Onde S, 2008. Impact of food concentration on diel vertical migration behaviour of Daphnia pulex under fish predation risk. Hydrobiologia 614:321-327.

Bollens SM, Rollwagen-Bollens G, Quenette JA, Bochdansky $\mathrm{AB}, 2011$. Cascading migrations and implications for vertical fluxes in pelagic ecosystems. J. Plankton Res. 33: 349-355.

Bottrell HH, Duncan A, Gliwicz ZM, Grygierek E, Herzig A, Hillbright-Ilkowska A, Kurasawa H, Larsson P, Weglenska T, 1976. A review of some problems in zooplankton production studies. Contribution from the Plankton Ecology Group (IBP). Norw. J. Zool. 24:419-456.

Brandl Z, 2005. Freshwater copepods and rotifers: predators and their prey. Hydrobiologia 546:475-489.

Chang KH, Hanazato T, 2004. Diel vertical migrations of invertebrate predators (Leptodora kindtii, Thermocyclops tai- hokuensis, and Mesocyclops sp.) in a shallow, eutrophic lake. Hydrobiologia 528:249-259.

Chang KH, Hanazato T, 2005. Prey handling time and ingestion probability for Mesocyclops sp. predation on small cladoceran species Bosmina longirostris, Bosminopsis deitersi, and Scapholeberis mucronata. Limnology 6:39-44.

Clesceri LS, Greenberg AE, Eaton AD, 1998. Standard methods for the examination of water and wastewater. 20. American Public Health Association.

Cole GA, 1983. Textbook of limnology. 3. The C.V. Mosby Co., London: $401 \mathrm{pp}$.

Culver DA, Boucherle MM, Bean DJ, Fletcher JW, 1985. Biomass of freshwater crustacean zooplankton from lengthweight regressions. Can. J. Fish Aquat. Sci. 42:1380-1390.

Dodson SI, 1990. Predicting diel vertical migration of zooplankton. Limnol. Oceanogr. 35:1195-1200.

Dragoş N, Péterfi LŞ, Momeu L, Popescu C, 1997. An introduction to the algae and the culture collection of algae at the Institute of Biological Research Cluj-Napoca. Cluj University Press: $267 \mathrm{pp}$.

Erhan MG, 2008. Diel vertical migration of planktonic crustacean populations in the Izvorul Muntelui - Bicaz Reservoir. Anal. Şt. Univ. Al.I.Cuza Iaşi Biol. Anim. 54:145-151.

Frost BW, Bollens SM, 1992. Variability of diel vertical migration in the marine planktonic copepod Pseudocalanus newmani in relation to its predators. Can. J. Fish Aquat. Sci. 49:1137-1141.

Gliwicz ZM, Pijanowska J, 1988. Effect of predation and resource distribution on vertical migration of zooplankton. Bull. Mar. Sci. 43:695-709.

Gliwicz ZM, Biernacka A, Pijanowska J, Korsak R, 2000. Ontogenic shifts in the migratory behaviour of Chaoborus flavicans Meigen: field and experimental evidence. Arch. Hydrobiol. 149:193-212.

Halat KM, Lehman JT, 1996. Temperature-dependent energetics of Chaoborus populations: hypothesis for anomalous distributions in the great lakes of East Africa. Hydrobiologia 330:31-36

Haney JF, 1993. Environmental control of diel vertical migration behaviour. Arch. Hydrobiol. Beih. Ergeb. Limnol. 39:1-17.

Haney JF, Hall DJ, 1973. Sugar-coated Daphnia: a preservation technique for Cladocera. Limnol. Oceanogr. 18:331-333.

Horppila J, Malinen T, Nurminen L, Tallberg P, Vinni M, 2000. A metalimnetic oxygen minimum indirectly contributing to the low biomass of cladocerans in Lake Hiidenvesi - a diurnal study on the refuge effect. Hydrobiologia 436:81-90.

Jakobsen PJ, Johnsen GH, 1987. Behavioural response of the water flea Daphnia pulex to a gradient in food concentration. Anim. Behav. 35:1891-1895.

Kozhov M, 1963. Lake Baikal and its life. Junk, The Hague: $344 \mathrm{pp}$.

Lampert W, 1993. Ultimate causes of diel vertical migration of zooplankton: new evidence for the predator avoidance hypothesis. Arch. Hydrobiol. Beih. Ergeb. Limnol. 39:79-88.

Lampert W, McCauley E, Manly BFJ, 2003. Trade-offs in the vertical distribution of zooplankton: Ideal free distribution with costs? P. Roy. Soc. Lond. B Bio. 270:765-773.

Lampert W, Sommer U, 2007. Limnoecology. 2. Oxford University Press: 324 pp.

Larsson P, 1997. Ideal free distribution in Daphnia? Are daph- 
nids able to consider both the food patch quality and the position of competitors? Hydrobiologia 360:143-152.

Leibold MA, 1990. Resources and predation can affect the vertical distribution of zooplankton. Limnol. Oceanogr. 35: 938-944.

Low EW, Clews E, Todd PA, Tai YC, Ng PKL, 2010. Top-down control of phytoplankton by zooplankton in tropical reservoirs in Singapore? Raffles B. Zool. 58: 311-322.

Michaloudi E, 2005. Dry weights of the zooplankton of Lake Mikri Prespa. Belg. J. Zool. 135:223-227.

Neill WE, 1981. Impact of Chaoborus predation upon the structure and dynamics of a crustacean zooplankton community. Oecologia 48:164-177.

Neill WE, 1990. Induced vertical migration in copepods as a defense against invertebrate predation. Nature 345:524-526.

Oda S, Hanazato, T, 2008. Diel vertical migration patterns in two populations of Chaoborus flavicans larvae (Diptera: Chaoboridae) in response to fish kairomones, J. Limnol. 67:93-99.

Pearre S, 2003. Eat and run? The hunger/satiation hypothesis in vertical migration: history, evidence and consequences. Biol. Rev. 78:1-79.

Rine HE, Kesler DH, 2001. A long-term study of larval Chaoborus punctipennis (Diptera: Insecta) vertical migration and the role of critical oxygen concentration. J. Freshwater Ecol. 16:145-150.

Ringelberg J, Van Gool E, 2003. On the combined analysis of proximate and ultimate aspects in diel vertical migration (DVM) research. Hydrobiologia 491:85-90.

Ringelberg J, Flik BLG, Lindenaar D, Royackers K, 1991. Diel vertical migration of Daphnia hyalina (sensu latiori) in Lake Maarsseveen. Part 1. Aspects of seasonal and daily timing. Arch. Hydrobiol. 121:129-145.

Rujinschi RI, Rujinschi C, 1970. [Some aspects of the diurnal and nocturnal migration of zooplankton in the station Rug- inești - water reservoir Bicaz].[Article in Romanian]. Lucr. St. Cercet. Biol. Geol. Geogr. Stejarul 267-280.

Santer B, 1993. Potential importance of algae in the diet of adult Cyclops vicinus. Freshwater Biol. 30:269-278.

Santer B, 1996. Nutritional suitability of the dinoflagellate Ceratium furcoides for four copepod. J. Plankton Res. 18: 323-333.

Sæther OA, 1997. Diptera Chaoboridae, phantom midges, p. 149-161. In: A. Nilsson (ed.), Aquatic insects of North Europe. 2. Apollo Books, Stenstrup.

Şerban G, Sorocovschi V, 2003. [Lake Ştiucii - The Transylvanian Plain].[Article in Romanian]. Stud. Univ. Babeş-Bolyai Geogr. 48:47-54.

Sommer U, Sommer F, Santer B, Zöllner E, Jürgens K, Jamieson C, Boersma M, Gocke K, 2003. Daphnia versus copepod impact on summer phytoplankton: functional compensation at both trophic levels. Oecologia 135:639-647.

Stich HB, Lampert W, 1981. Predator evasion as an explanation of diurnal vertical migration by zooplankton. Nature 293:396-398.

Wetzel RG, 2001. Limnology, lake and river ecosystems. 3. Academic Press: 1006 pp.

Wright D, Shapiro J, 1990. Refuge availability: a key to understand the summer disappearance of Daphnia. Freshwater Biol. 24:43-62.

Wright D, O'Brien WJ, Vinyard GL, 1980. Adaptive value of vertical migration: a simulation model argument for the predation hypothesis, p. 138-147. In: W.C. Kerfoot (ed.), Evolution and ecology of zooplankton communities. University Press of New England, Hanover.

Zaret RE, Kerfoot C, 1980. The shape and swimming technique of Bosmina longirostris. Limnol. Oceanogr. 25:126-133.

Zaret MT, Suffern JS, 1976. Vertical migration in zooplankton as a predator avoidance mechanism. Limnol. Oceanogr. 21:804-813 